\title{
Criminal Law Dilemmas in Withholding and Withdrawal of Intensive Care
}

\author{
DAMJAN KOROŠEC
}

\begin{abstract}
Regarding the question under which conditions a physician in Slovenia is allowed to omit life-prolonging medical treatment of dying patients, the main legal source is the Patient Rights Act, adopted in Slovenia in 2008 (parallel to Criminal Code of Slovenia). Under this law, there are two possible circumstances in deciding about life-prolonging medical treatment regarding dying patients: a) on the basis of the so-called patient's testament in the sense of Art. 34 of the Patient Rights Act; and b) without any known patient's testament in the sense of Art. 34 of the Patient Rights Act. Such decisions can also be contrary to a decisive wish of relatives of the dying patient to prolong the patient's life under all circumstances. If this decision is reached with full respect of the Patient Rights Act as well as the rules of medical science, omitting life prolonging medical treatment cannot be unlawful in the sense of medical criminal law.
\end{abstract}

KEYWORDS: $\cdot$ cubstantive criminal law $\bullet$ omission $\bullet$ life prolonging medical treatment $\cdot$ Slovenia

Correspondence AdDress: Damjan Korošec, Ph.D., Professor, University of Ljubljana, Faculty of Law, Poljanski nasip 2, 1000 Ljubljana, Slovenia, email: damjan.korosec@pf.uni-lj.si. 

Care

In medical ethics, the issue of withholding and withdrawal of treatment with reference to the so-called futility of prolonging a failing human life is one of the most prominent topics. Among its activities, Slovenian National Medical Ethics Committee has especially frequently and intensely focused on these issues, also thanks to a distinctly personal involvement of its long-time president, the academic Jože Trontelj, in this topic ${ }^{1}$. Both him and the committee have thus developed several guidelines to identify such situations and their philosophical, ethical, medical, as well as legal distinction from another problem, known as euthanasia (sometimes specifically declared as the so-called passive euthanasia) ${ }^{2}$. The so-called futile treatment (when life is ending) is not considered euthanasia, even though according to the known legal theories of causation, including the theory of attributing a potential prohibited consequence to a potentially induced act of omission, the omitted health-care measures would with probability bordering on certainty at least somewhat prolong a specific (dying) patient's life. For that reason, the insistence on absence of medical error and therefore also of physician's error became a standard in such cases, leading to a complete obstruction of all civil, administrative and criminal liability already at the level of substance of criminal conduct, and with it of any damage liability, disciplinary liability, liability for misdemeanour and particularly criminal liability of healthcare workers, including physicians in such cases.

This applies first of all (A) in situations where the patient is currently still physically and mentally sufficiently capable of refusing certain health-care measures, even if they would prolong his life, as well as in situations where the patient has with pre-emptive declaration ordered omission of certain health-care measures in case particular medical conditions occur. Following the enactment of Patient Rights Act (ZPacP, Official Gazette of the RS No. 15/08 of 11 February 2008 ) in 2008 and its many provisions on protection of patients' autonomy, including by the previously asserted will (especially Article $34 \mathrm{ZPacP}$ ), numerous ideas and criteria of medical ethics related to the consideration of a patient's will even when leading to lethal outcome have found their way into current health-care legislation. Through the blank legislative technique, the same was also very clearly accepted by new Slovenian substantive criminal law that was adopted the same year (KZ-1 of 2008, hereinafter summarized in version UPB2, Official Gazette of the RS, No. 50/12 of 29 June 2012).

Absence of medical and therefore of physician's error in terms of the so-called futility of prolonging an ending human life at least potentially also applies in cases (B), where conclusions on futility cannot be based on the patient's own will and even do not follow from the opinion of his health-care proxy (in terms of $\mathrm{ZPacP}^{3}$ ) or their relatives, who are generally responsible to actually pursue the patient's best interests, which at first glance in principle also essentially include preservation of his life, and who are likely to argue in favour of prolonging a 
dying patient's life at any cost, despite medical assessment of the so-called futility of such measures in a specific case. Here, medical ethics in principle recognizes the same objective criteria for assessing the futility of treatment in specific cases, but in regard to a possible opposition by a health-care proxy or patient's relatives when death is a probable outcome of omission of certain health-care measures, no clear solution was to be found in legislation, unlike in cases of current or previously expressed will of the patient himself.

This article analyses from the perspective of criminal law theory and legislation in Slovenia the withholding and withdrawal of (intensive) care with potential or actual outcome in the form of shortening of patient's life in terms of the so-called futility of prolonging a failing human life, as these conditions are identified and recognized by medical profession ${ }^{4}$.

\section{Criminal law distinction between the withholding and withdrawal of treatment}

Older substantive criminal law theory has traditionally considered that unlike the withholding and withdrawal of measures that deter a threat to, or injury to, any criminal law asset (therefore also of health-care measures for prolonging a patient's life), which are obviously omissive types of acts (German: die Unterlassung) in the sense of the first element of a multi-part general concept of criminal offence ${ }^{5}$, the discontinuation of such measures that have already started (particularly, for example, turning off ventilators, infusion pumps, etc.) is considered a type of a induced act (German: das Tun) in terms of criminal conduct.

Current literature in this field has reversed the position. As can be read, for example, in one of the most representative works in this particular theoretical field, a marvellous monograph on the withdrawal of omissive causal courses (Haas, 2002), all cases where one's death realizes as a threat that has [acutely] existed prior to the withdrawal of aid, including the withdrawal of previously established treatment, are considered acts of omission, not induced acts. In simplified terms, this is about a new answer to the question whether the withdrawal of causal course of rescue by suspension of one's own rescue efforts when they have not yet been fully exhausted ${ }^{6}$, is considered a (continuing) omission or an (typically non-continuing) induced act. Currently, at least in these cases, a special construct of the so-called omission by induced act, which has until recently been rather uniformly supported by criminal law, is being abandoned ${ }^{7}$. Even broader, in all cases where the offender with his actions prevents or neutralizes the opportunity to secure objectives protected by criminal law, after he himself created this opportunity through his rescue efforts (typically also when he turns off a device that can effectively prolong a patient's life, if he was the one 
D. Korošec: Criminal Law Dilemmas in Withholding and Withdrawal of Intensive Care

who used the machine on the patient in the first place), such withdrawal is considered an act of omission.

In this context, in the most recent criminal law a functional boundary between the withholding and withdrawal of treatment (which extends the life of the dying patient) is disappearing, and this article will likewise be based on the omissive nature of acts of withdrawal hereby considered (and thus on the basic usefulness of omissive incriminations in Slovenian criminal law $)^{8}$.

\section{Criminal offense of failure to render medical aid in criminal law system}

Omission of medical treatment is recognized by KZ-1 as a special criminal offence in Chapter XX (Criminal offences against public health). In Article 178, under the heading "Failure to render medical aid," the code provides:

"(1) A physician or any other medical employee who breaches the terms of his professional duty by failing to render aid to a patient or any person whose life is in danger shall be sentenced to imprisonment for not more than one year.

(2) The act referred to in the preceding paragraph shall not be unlawful if a physician withdraws a method of treatment, surgery or medical procedure at the explicit written request of a patient or other person who is able to make a decision about himself and also refuses help after being informed about the necessity of treatment and possible consequences of refusing it, and also after the physician has again tried to persuade such a person to change his decision."

Incrimination norm is explicitly blank, the offender in this criminal offence can only be a physician or other medical employee (in regard to the offender, the criminal offence is special, delictum proprium). In terms of description of criminal conduct, the norm is very simple, albeit genuinely omissive. Because the norm is explicitly omissive, quasi-omissive manner of conduct is not possible. In accordance with general rules on criminal attempt, the latter is not punishable, since the prescribed sentence is low (an inappropriate attempt, which is otherwise generally possible for true acts of omission) ${ }^{9}$.

Slovenian legislature does not escalate incrimination of failure to render medical aid depending on helplessness of a victim; unlike, for example, assistance in suicide criminalised in Article 120 of KZ-1 (which is at least theoretically possible even in the quasi-omissive manner).Thus, the term "patient, or any person" in Article 178 of KZ-1 refers to anyone, including children (under 14 years of age), a minor over 14 years of age, disabled person or a potential beneficiary of healthcare services who is otherwise in need of special social protection. 
Incrimination of failure to render medical aid does not contain the objective condition for punishment, does not show any special signs of collectivity, and being a true omission, it is of course continuous, with all dogmatic implications of this definition, including those relating to temporal application of criminal law and period of limitation. The offence is not composite.

In any case, punishable are all manners of participation in the broadest theoretical sense of the word without any specific limitations.

Since the enactment of ZPacP and its definition of a patient and implicitly of a sick person (2/I (16). Article ZPacP), it is not completely clear what the element "non-patient" (from "patient or any person") from the first paragraph of Article 178 of KZ-1 should now encompass. Who could require medical aid (sic!) in the context of rules of medicine, but is at the same time not a patient, i.e. not ill, and can explicitly also not be considered a patient? In other words, from the perspective of systematic legislative technique, it is not clear why the legislator was not satisfied with logically more general "someone" (or even significantly better "another" ${ }^{10}$ ), if for substantively unclear reasons it already refused to enact a new blank definition of a legal (!) term patient in Article 178 of KZ-1. Everything indicates that we are witnessing an unnecessary terminological ambiguity or even substantive confusion that points to a legislative error.

Death or any form of impairment of health are not a prohibited consequence of Article 178 of KZ-1 (neither did the legislator intend to include them in the form of some objective condition of punishability, such as can be found, for example, as a special form of health impairment in one of the most fundamental incriminations in Slovenian medical criminal law, namely negligent treatment under Article 179 of KZ-1); instead, that would be abandoning a person to his fate despite possible, available, achievable, and feasible professional aid, potentially damaging general trust of public in the health-care system. Should a physician or other medical employee cause a person's death with his intentional failure to render aid (passivity) "contrary to his professional duty", his conduct would in case of properly proven negligence be considered a real ideal concurrence with criminal offence of negligent homicide under Article 117 of KZ-1 (in the quasi-omissive manner of conduct, although the term "to cause" could generally refer to both induced acts and acts of omission). Slovenian legislator has not only refrained from including objective conditions of punishability in Article 178 of KZ-1, but also from the possibility of applying a notion of liability for aggravated consequence, and has thereby also not foreseen a patient's death in that context.

Something different is a convergence of (necessarily intentional) real omissive incrimination of failure to render medical aid under Article 178 of KZ-1 and intentional manslaughter of a patient when it occurs in the quasi-omissive manner of conduct (e.g. when the offender's motive is mercy). At this point, it is necessary 
to note that even when discussing suicide itself, at least in theory there are no reasons against recognition of its omissive nature (didactically typical: a drowning persons stops fighting for his life with a wish to die, an attacked person stops resisting a wild animal with a wish to shorten his suffering and die, and at least theoretically, a patient can also stop cooperating with his physician with a wish to die). Therefore, we could at least theoretically talk about omissive participation in omissive suicide, with all complicated dogmatic problems in such combination of conducts ${ }^{11}$. In any case, omissive participation in omissive or induced suicide is a case of dogmatically complex tangle of interests and causality in real- and quasiomissions (which are generally a result of incorrectly determined real omissions in legislation; of deficient theoretical knowledge of substantive criminal law and resulting legislative errors), which raises a question whether Article 178 of KZ-1 and regulation of intentional manslaughter-related offences in KZ-1 (especially manslaughter and murder under Articles 115 and 116) are in the mutual relationship of specialty (and therefore only apparent ideal concurrence exists) or complementarity (and the ideal concurrence is real).

Dogmatically, complementarity of quasi- and real omissive offences in such cases of convergence of only partially related offences is not at all excluded; thus, it is theoretically possible to allow for a real ideal concurrence of failure to render medical aid under Article 178 of KZ-1 and quasi-omissive manslaughter or murder (under Articles 115 or 116 of KZ-1) in case of special helplessness of a victim in circumstances that potentially justify particularly qualifications of qualified murder under Article 116/I(1) of KZ-1 (treacherous manner). In my opinion, a real ideal concurrence is despite a large difference in gravity of a relatively frivolous offence of failure to render medical aid and of murder as one of the worst offences in Slovenian legislation at least potentially justified because of a very pronounced disponible-non-disponible complexity of the less serious criminal offence. The incrimination of failure to render medical aid from Article 178 of KZ-1 without a doubt represents convergence of a fully disponible objective of certain person's health and personal safety (in relation to health-care, especially in health-care institution as part of the health-care system) with at least partly non-disponible objective of basic humanity in health-care and with a very pronounced non-disponible objective of public trust in professional functioning of health-care system (in short, public trust in the health-care system), which is in all criminal legal systems, which are familiar with such incrimination, considered a significant, if not central criminal law objective. Public trust and basic humanity in this context are not necessarily sufficiently non-legally included under a very general notion of the duty to prevent harm; therefore, complementarity of these objectives in the form of a real ideal concurrence of these intentional criminal offences might be needed.

On the other hand, the idea of a simple specialty of physician's serious intentional offence of manslaughter in quasi-omissive form of conduct (which is based on the physician's duty to prevent harming of a patient and therefore to some extent 
includes non-legal logic of real omission of medical aid from Article 178 of KZ-1) is attractive despite the fact that intentional manslaughter-related offences are placed in different chapters of KZ-1 and despite the apparent complexity of criminal law objectives in incrimination of failure to render medical aid under Article 178 of KZ-1. Such approach may be more akin to Slovenian case law.

Due to the lack of relevant final judgements in this special field (after the enactment of KZ-1), we can only wait for future developments and once again conclude that Slovenian criminal law is in urgent need of a thorough reconstruction of the notion of aggravated consequence at least in the special part of criminal legislation. The discussed issue of ideal concurrences of intended criminal offences is in my opinion also a good textbook example of how useful it would be for Slovenia to introduce a notion of liability for aggravated consequence for intended aggravated consequences as well, the same as in Germany $^{12}$, or, if the legislator is not able to seriously consider this issue, to simply abolish the notion of liability for aggravated consequence altogether. In this case, both criminal legal theory and the legislator would have to find new ways to correct legislator's strange - in terms of values and legislative system avoidance of a practically very likely consequence of real omissive conduct of failure to render medical aid from Article 178 of KZ-1: the death of the patient. Due to given empirical probability, it firmly seems that legislative regulation of a patient's death would in natural framework of a death-related part undoubtedly fit into the specially framed real omissive incrimination of Article 178 of KZ-1. It seems counter-productive that by ignoring this problem, the legislator charges users with very complicated decisions on concurrences between real and quasiomissive incriminations with such strong dogmatic implications as in combinations discussed herein.

Relationship between incriminations of failure to render medical aid from Article 178 of KZ-1 and assistance in suicide from Article 120 of KZ-1 (in doubtlessly possible quasi-omissive form) is somewhat complex and makes the answer about a possibility of a real ideal concurrence between the two difficult. On the one hand, it seems obvious that both incriminations of assistance in suicide from Article 120 of KZ-1 and of failure to render medical aid from Article 178 of KZ-1 primarily protect human life (even if human life as the object of protection of incrimination of assistance in suicide openly appears as a central protected objective, while in incrimination of failure to render medical aid, protection of human life is only secondary, considering the fact that this criminal offence was included in a chapter on criminal offences against public health, with public trust in health-care system being central instead). Therefore, it seems that a potential relationship of specialty between the two, which might prevent the construction of a real ideal concurrence, is possible. However, it is not necessarily clear which of the discussed criminal offences is more special. 

Care

Since the incrimination of assistance in suicide from Article 120 of KZ-1 in its quasi-omissive form is notably more serious and a more developed form of incrimination when compared to failure to render medical aid from Article 178 of KZ-1 (prescribed sentences are up to ten times higher compared to failure to render medical aid from Article 178 of KZ-1, and unlike Article 178 of KZ-1, Article 120 of KZ-1 includes quite a few privileged and qualified forms), it seems that Article 120 is more special of the two.

On the other hand, it is also true that incrimination of assistance in suicide with respect to the offender is shaped as a general criminal offence (delictum commune, delictum non-proprium), but above all it does not pursue specific objectives of public trust in the health-care system, which are a natural upgrade of criminal law objectives of health and thus of life, apparently unlike incrimination from Article 178 of KZ-1. In light of these arguments, Article 178 of KZ-1 is more special. That is why, in my opinion, the discussed incriminations are in mutual relationship of complementarity, not in relation of specialty, and it is therefore necessary to recognize the possibility of a real ideal concurrence of criminal offences from Articles 120 and 178 of KZ-1.

Unfortunately, these observations could not be verified or illustrated in Slovenian criminal judicial system on the basis of available data, because such combination has not yet appeared in practice; therefore, it will be that much more interesting to follow development of argumentation related to such concurrences in theory and practice in the future.

Since a criminal offence of failure to render medical aid under Article 178 of KZ1 is a special form of general failure to render aid (Article 130 of KZ-1), a real ideal concurrence between these two criminal offences is not possible because of the principle of specialty.

\section{$4 \quad$ Futility of treatment at the end of life as an issue of exclusion of substance of criminal offence or of illegality?}

A patient's direct refusal of medical aid under general assumptions of free choice, especially if appropriately accompanied by a physician's duty to inform the patient, excludes illegality of failure to render aid in Slovenian criminal law. This was the case even before the enactment of ZPacP (in 2008), and is even more evident after implementation of numerous provisions of this act on the protection of patient's autonomy. It is not necessarily entirely clear whether this is due to a blank nature of incrimination of failure to render medical aid from Article 178 of KZ-1 (where such refusal excludes medical error according to the rules of medicine - failure to render aid is no longer "contrary to professional duty" of the physician in the context of blank Article 178 of KZ-1) or because of refusal of medical aid according to the criteria of general notion of consent (refusal) of a 
potential victim in criminal law. In these cases, forced aid remains illegal under certain conditions as general criminal offence of coercion (according to Article 132 of KZ-1), if not of causing bodily harm.

A particular problem in criminal law, especially from evidence law perspective, is advance refusal of treatment under certain predetermined circumstances, which is as a notion of the patient's testament included in Article 34 of ZPacP and is through blank legislative logic recognized by substantive criminal law, including, and in particular, in the scope of incrimination of failure to render medical aid from Article 178 of KZ-1.

There are legally speaking generally two types of expert decisions related to medical treatment or omissions of measures that can be described as implementation (realization) of expert decisions on futility of treatment at the end of life:

- on the basis of the patient's advance decision within the meaning of Article 34 of ZPacP (summarised below);

"(1) Every patient with full disposing capacity and who is of legal age has the right to have his will regarding rejection of treatment heeded if he should be in a position where he is incapable of expressing his will for cases where:

- he should suffer from grave illness, which given the ability of modern medicine would lead to death in a short period of time in spite of medical treatment or medical care, or for which treatment or care would not lead to an improvement in health or the alleviation of his/her suffering but rather only to the prolonging of his life;

- his life would be prolonged by medical treatment or care, but he would end up being in a state where, due to the graveness of his disability, he would lose physical and mental ability to take care of himself.

(2) The patient's wishes from the first indent of previous paragraph are binding for the attending doctor, whereas his wishes in the second indent of previous paragraph are considered by the doctor as a guide in deciding on the course of treatment.

(3) The patient's will, expressed in advance, shall be respected when the above-described situation occurs, if at the same time no reasonable doubt arises on whether the patient would revoke his will under given circumstances."

- without any properly documented patient's advance decision within the meaning of Article 34 of ZPacP.

In case of the first indent of the first paragraph of Article 34 of ZPacP, only realization of the patient's previously expressed will is permissible and required (with possible restrictions from the third paragraph - indications of will to revoke). The only permitted exception here would be, for example, if "there are indications that the patient would revoke his previously expressed will", and the physician 

Care

would in such case not be punished mainly because of appropriate justification of facts on which such reasoning is based. It is understood that this could only be a very exceptional situation, since broad application of such exception would in practice undermine the basic intention of Article 34 of ZPacP, and extremely restrictive interpretation of the exception from the third paragraph of Article 34 of $\mathrm{ZPacP}$ is therefore teleologically necessary.

In case of the second indent of the first paragraph of Article 34 of ZPacP, it is legally binding to respect the patient's previously expressed will in decisionmaking. From the perspective of evidence law, it is very sensible to adequately formally describe facts and arguments for a decision that it will not be respected in a specific case (professional assessment). This argumentation must make it clear that previously expressed will was known and sufficiently considered when making the decision. A routine refusal would be contrary to the intention of Article 34 of ZPacP.

In all cases without a documented advance decision by the patient, all general rules of decision-making shall apply when the patient cannot decide for himself (theoretically preferable is a direct decision by the patient, but the latter will in these cases be technically very unlikely due to "the seriousness of medical condition" at the end of life), as they are precisely determined in ZPacP: decisionmaking through the health-care proxy, relatives and similar.

Medical opposition against the will of alternative decision-makers is essentially a replacement of judicial ruling on the patient's rights. Accordingly, it must be precisely and carefully justified in medical documentation (including special forms prescribed for this purpose). The likelihood that the patient's relatives will in such cases perceive such decision as the killing of the patient is in practice very high and seeking retribution before the court is very likely. Therefore, evidentiary weight of documented circumstances of such decisions will in practice be essential. In my humble personal opinion, justification that the withholding and withdrawal of life-prolonging treatment is "in the best interest of a particular patient" is potentially very difficult to accept from the perspective of public opinion; the fact needs to be considered that many relatives will in practice have difficulties understanding this kind of reasoning and may consider themselves outmanoeuvred in their role as a guardian of the dying person's life. Careful documentation of developments in certain case will be very important for physician's legal security.

It seems that in case of previously expressed will under Article 34 of ZPacP, rules of refusal in terms of negation of consent - therefore, rules of consent - apply in the context of criminal law dogma. Thus, in accordance with a generally accepted modern view of the multi-part general concept of criminal offence, we are dealing with exclusion of illegality of failure to render medical aid. On the other hand, the explicitly blank formulation of incrimination of failure to render medical aid from 
178 of KZ-1 in the key blank part ("contrary to his professional duty") raises a question whether the rules of consent, and thus of refusal of medical aid (direct and in advance, as well as substitute) can simply be subsumed under rules of professional duty in health-care, in particular of physicians, which would transfer the issue of consent (refusal) to an even more elementary level - substance of criminal offence as an element of general concept of criminal offence. It seems that with the phrase "contrary to professional duty" in this incriminating provision, the legislator seeks to achieve the most elementary possible exclusion of the existence of criminal offence in the context of legal regulation of elements of general concept of criminal offence and general theory of general concept of criminal offence, namely exclusion of the substance of the offence. Such definition is, after all, because of a greater symbolic radicalism of official conclusion that the offence does not exist (and not that the later exists, but is not illegal in terms of opposition to the law as a system of norms and values) in favour of the defendant and, as such, already the most acceptable. However, it cannot be stressed enough that, in any case, such a conclusion can only be based on the dogma of consent, which is typically an issue of illegality as an element of general concept of criminal offence, and that a strict separation of these two elements of effects in such circumstances is therefore not possible, nor dogmatically particularly sensible.

In cases where we are not dealing with current or previously expressed will of the patient, but instead with decisions of health-care proxy or relatives (focused on prolonging the patient's life with all medical possibilities and at any cost), the rules on substitute consent generally fail because of the potential or actual fatal result of withdrawal of treatment. The notion of substitute consent or refusal, as it is more or less generally known and is essentially part of cultural foundations, in accordance with general constitutional principles of social state and numerous unambiguous findings of criminal law theory in the field of consent as a reason for justification (exclusion of illegality) does not have justifiable effect if it leads to someone's death. Therefore, it is no longer unimportant whether we consider the futility of treatment of a dying person as a problem of non-existence of medical error or as a problem of consent (and indirectly of non-existence of medical error), or as a problem of non-existence of substance of criminal offence or of illegality. As we cannot axiomatically advance with the consent or substitute consent, exclusion of illegality with these institutes is not an option, and it seems that the only remaining institutes are an implied refusal by the patient and a direct application of medical professional error as a blank fulfilment of elements of criminal law provision, and thus of the substance of criminal offence of failure to render medical aid and quasi-omissive killing of the patient. 

Care dying

A special, characteristically translegal ground for justification was established by modern criminal law, namely a so-called implied consent and refusal by a potential victim ${ }^{13}$. This is an autonomous ground for justification that has historically developed from the notion of consent (refusal) and resembles a justifiable necessity. For all so-called disponibile assets of criminal law (whereby it should be noted that human life is because of certain ethical and legal concerns in modern criminal law only partly available), it is considered that encroachment upon such asset is not illegal if the holder of the asset did not give consent and the offender knows that consent was not, nor can it be, obtained, but indications of objective circumstances exist, that the holder of the asset would consent to a certain procedure if he was capable of doing so (and the offender encroaches upon the asset motivated by this knowledge). More legally professional: in punitive law, implied consent of a victim is generally defined as invoking those actually existing and perceivable circumstances from which it can reasonably be inferred that the individual as a potential victim of criminal offence would consent to certain encroachment upon his own legal interests, when it is clear that he neither consented nor objected, nor is he able to do so. This also applies mutatis mutandis for failure to render aid to the patient. Therefore, it seems at first that omission of medical treatment for prolonging life in terms of futile prolongation of dying person's suffering could be recognized as circumstances against which the patient could be considered to object if he could, and omission of such measures would in accordance with translegal notion of implied refusal be justified, therefore consistent with law as a system of norms and values.

The notion of implied consent (and refusal) can primarily be applied as a criminal law criterion of legality or illegality of conduct in all those circumstances where real consent of potential victim is not provided and also cannot be obtained, but it can reasonably be assumed that the affected would in full knowledge of the facts voluntarily allow or refuse certain encroachment upon his own criminal law assets; for example, because he does not want to helplessly suffer when dying. The purpose of this institution is consideration of indications that a particular person, despite his current inability to communicate, considered certain encroachment upon his assets, especially certain treatment, for whatever reasons either welcome or would, in case of awareness, at least not be opposed, or considers it unwanted or would, in case of awareness, be opposed.

The notion of implied consent is characterized by the fact that at the time the offence is committed, the offender is aware that no criminally valid consent exists. In this sense, the implied consent is not a sub-type of consent of a victim or a type of the offender's error, but is instead an autonomous institution. 
Philosophy of protection of individual's autonomy, intrinsic to the institution of implied consent, is different from philosophy of notion of necessity. Normative balancing of interests (harm of aversion and harm of danger that is threatening to occur without aversion) in the framework of necessity is according to modern theory of criminal law supposed to be too typical, too focused on average, too objectified, hostile to differences and legitimate uniqueness of the individual, including or especially in his role as a patient. Criteria of necessity should therefore at least in case of encroachment upon fully available criminal law assets, among which the body is the most characteristic, consistently make way to criteria of implied consent. Only if specific indications of the will of the affected are not present and cannot be obtained, general rules of necessity with the so-called statistical scales of values apply.

There are at least two fundamental issues with this reasoning. First, when the omission potentially or actually results in death, we encounter the already mentioned so-called disponibility ${ }^{14}$ of life as a criminal law asset. To put it simply, the individual is in principle free to dispose with his own life, including the omissive or induced suicide, but in terms of criminal law, he cannot justifiably involve other persons. His authorisation to take life does not exclude illegality of such authorisation (euthanasia, assistance in suicide, requested taking of life). At least according to traditional general criminal law theory, this also applies for authorisations of omissions related to dying: in principle, help should be provided at least from the moment when the patient loses consciousness, otherwise real and quasi-omissive offences occur independently of refusal of treatment. The reason is, as mentioned above, limited disponibility of human life for a direct holder of this most important criminal asset. It seems that such reasoning in criminal law should a fortiori necessarily also be applied to the notion of implied consent of a potential victim. If direct refusal is not relevant in this context, this is even more true for the implied refusal! This generally neutralizes the general notion of implied consent (refusal) in cases of omission of treatment, even if its assumed to be futile for the dying, any time we are dealing with potential or actual shortening of a patient's life.

Another problem with the use of notion of patient's implied consent is its legal concretisation in medical administrative law. The notion is explicitly recognized by Slovenian legislation; we find it in the provision of Article 24 of ZPacP. The later reads as follows: "Medical procedure or health-care treatment [...] can be administered to a patient without his consent under the following conditions:

- the patient does not have disposing capability,

- the physician does not or cannot know that the patient, his health-care proxy, his authorised representative, or another person who is legally authorised to give consent, are opposed to the treatment,

- consent of persons listed in previous case cannot be obtained in a reasonable time and 
- medical procedure or treatment would be in the best interest of the patient's health"

There is no doubt that from the perspective of criminal law, Article 29 of ZPacP regulates the so-called implied consent in part about physician's awareness of the will of the patient who is not able to decide for himself ("the physician does not or cannot know that the patient [who does not have disposing capability] [...] is opposed to the treatment").Even if the implied consent from the second indent of the first paragraph of Article 29 in conjunction with the first indent of the same paragraph is in fact very concealed, and is at least in terms of the doctrine of consent of a victim in criminal law very unusually at the same time and somehow shyly regarded by ZPacP together with substitute consent (health-care proxy, authorised representative or other persons authorised to give consent, as listed in the second part of the second indent), there can nevertheless be little doubt that for the first time in legislative history, ZPacP has in 2008 introduced a legally regulated notion of patient's implied consent in Slovenian medical law and thus indirectly also in medical criminal law.

In terms of comparative law, this is a rather new, typically translegal, i.e. in punitive law and particularly in criminal legislation not regulated, institution of general part of punitive law. This means, that as a punitive law - and naturally also criminal law - institution, it is valid and applicable even if it is not specifically governed by any legal act and would remain in force in Slovenia even if ZPacP would offer no specific criteria, such as those found in Article 29. Since the enactment of ZPacP and especially of the article discussed here, this institution will in Slovenia be legally (even if outside of criminal legislation) justified and it is expected that recognisability and importance of theoretical criminal law notion of implied consent will therefore also increase.

Although the second indent of Article 29 of ZPacP only refers to implied consent for active, induced treatment ("the physician does not or cannot know that the patient, his health-care proxy, his authorised representative, or another person who is legally authorised to give consent, are opposed to the treatment") and the article does not regulate implied refusal of treatment in this indent or anywhere else, the position of Slovenian punitive and therefore also criminal law remains that the notion of implied consent is at least in theory also useful in assessment of illegality of failure to render medical aid. In such cases, we are talking about implied refusal. An example would be a necessity to stitch a minor wound of the patient who has hitherto always consistently refuse any medical aid, or has perhaps for some extremely unusual, uncommon reasons, which are to the average observer difficult to understand, in particular refused stitching. In criminal law theory, and in other countries in case law as well, the notion of implied consent, i.e. more specifically a patient's implied refusal, is also gaining in importance in cases where the patient is in danger of dying because of failure to render medical aid. A typical example is a poisoned person who is carrying a written statement 
that he poisoned himself with intention to commit suicide and does not want any treatment. Even though (forced) aid in such life-threatening situations nowadays generally cannot be considered illegal and especially not unlawful from criminal law perspective, a physician who would in such case respect the patient's will would objectively fulfil the elements of some form of incrimination of failure to render medical aid with fatal result, but his conduct could according to the criteria of implied consent potentially be considered justified (even if such a position is frankly not ethical nor necessarily universally accepted).

In the scope of Article 29 of $\mathrm{ZPacP}$, the objective justification of assumption that the victim would, having knowledge of the facts, at the given moment freely consent to a specific treatment or omission of treatment, wherein his will is relevant in terms of criminal law, is particularly crucial for the existence of criminal offence of forced medical intervention (bodily harm due to noncompliance with the will of the patient), and essentially with application by analogy also for failure to render medical aid.

In theory of modern criminal law, implied refusal of aid is particularly interesting in case of the so-called fatal decisions to omit resuscitation. Criminal courts in compared foreign countries in such cases, mainly because of some special respect for life and partly with reference to human dignity (which is because of separation of dignity from autonomy and freedom in such reasoning constitutionally necessarily very problematic, and human dignity remains strangely hollow) sometimes still insist on a duty to provide aid despite the very clear indications for free will of the patient in terms of refusal of aid. In other words: even in Slovenia (which is comparatively traditionally particularly unfavourable towards the patient's autonomy in criminal law) it cannot be denied that a health-care employee risks conviction for criminal offence of failure to render medical aid (with fatal outcome, i.e. together with liability for the patient's death), if despite the textbook clear implied refusal of treatment by the patient, he fails to render aid in order to respect his will (and this leads to the patient's death). It cannot be stressed enough that such risk in terms of modern understanding of the notion of implied consent of the victim in modern criminal law (especially in practice) applies only to omissions with fatal result. In all other cases, the autonomy of a potential victim, including the patient, doubtlessly prevails, and the discussed risks to the health-care employee generally no longer exist: if a procedure is carried out in violation of Article 29 of $\mathrm{ZPacP}$, if the presumption of consent or refusal of the patient is not justified under these rules, medical procedure or omission of procedure generally remain illegal and successful invocation of necessity (for justification of procedure or omission of procedure, which are not in line with the assumed will of the patient) is not an option. It is important that modern criminal law emphasizes the patient's right to be different, which also includes the right to eccentricity: in the assessment of implied consent, indications of possible objectively unreasonable will of a potential victim and non-conformist will of the 

Care

affected, as long as it is perceptible, should also be considered. Subjective wishes of the affected should be given general priority over their so-called objective interests. The purpose of implied consent of the victim is to prevent unacceptable paternalism of uninvited helpers. Paternalistic help, even if the intentions are good, must generally as a rule give way to protection of autonomy of the individual at risk. In this respect, it is difficult for criminal lawyer to understand the real substance and meaning of the condition from the last indent of the first paragraph of Article 29 of ZPacP, i.e. that medical treatment or care of the patient must be to his maximum medical benefit. This is obviously not a criterion that would in terms of logic of implied consent protect specifically the individual's autonomy, but rather a kind of medical rule, which is not necessarily in accordance with the described logic of implied consent of the patient as a safety net for his autonomy in especially unfavourable circumstances.

Legal standards "[the physician] could not know [that there is opposition to treatment]" from the second indent and "within a reasonable time [obtain consent or substitute consent for treatment]" from the third indent of Article $29 \mathrm{ZPacP}$ will just have to be complemented by Slovenian (criminal) case law. In terms of modern theory of general part of substantive criminal law, it is especially interesting that duty to obtain statement of will of persons entitled to substitute consent is mentioned in the article that is by its nature dedicated to the implied consent of the patient. In terms of systematisation, this provision in this article is not in its proper place from the perspective of criminal law: the notion of implied rejection can only apply or is useful in cases where personal and substitute consent are not an option. And from the perspective of criminal law systematics and logic, another, maybe the most unusual, restriction of the effect of implied consent in Slovenian ZPacP: ZPacP is in the fourth indent of Article 29 with implied consent justifying only medical procedures that are to the patient's "maximum medical benefit." This is an obvious medical professional standard that will in criminal procedures have to be explained by appropriate experts. Especially interesting is the fact that this standard is obviously very objectified and, as such, clearly in a very tense relation with fundamental logic of protection of individuality, diversity, eccentricity, in short, the autonomy of the patient, and thus the logic that has produced the notion of implied consent and is the sole reason for its continuous existence. It seems that the mentioned maximum medical benefits can in practice easily subdue a generally modern, to the patient's autonomy favourably inclined, spirit of the new Article 29 of ZPacP and with the logic of objectified paternalism repress criminal law notion of implied consent at a time when its development in Slovenia has just barely begun.

It is clear that a health-care employee's conduct should be motivated by the implied consent or refusal, if he wants to successfully invoke the notion of implied consent as a ground for exclusion of illegality of his induced or omissive conduct (the so-called subjective element of grounds for exclusion of illegality in regard to the offender). From the perspective of evidence law, it is very helpful for a health- 
care employee if his motive at the time of procedure or omission of procedure is documented as clearly as possible, or at least that a credible witness can confirm that the health-care employee has also considered these elements when making a decision (directed questioning of relatives, friends or acquaintances of the patient, etc.).

In the context of the title of this paper, i.e. within the discussion on withdrawal of treatment for prolonging the life of a dying patient, it certainly cannot be stressed enough that by the nature of things, we are dealing with a patient in a very serious state of health, whose life is very directly and very intensively endangered .These are precisely the patients for whom the notion of implied consent or refusal, as has been introduced in Slovenian legislation in 2008 with ZPacP (Article 29), as opposed to general criminal legal theory, is explicitly not intended! A provision of Article 29 of ZPacP is clearly expressly restricted only to non-urgent, less risky and less difficult medical procedures. These definitely do not include treatment with potential or actual effect of shortened life. Therefore, for purposes in question, the notion of implied rejection of the patient as a reason for exclusion of illegality or even of substance of criminal offence of failure to render medical aid or even of omissive offences related to taking of life under Slovenian legislation is not an option. Because it is very clear that this institution is legally excluded from essentially all for the patient really crucial decisions in health-care, a subsidiary use of translegal institution of implied consent (refusal) in criminal law is also excluded, in accordance with general principle of interpretation a maiori ad minus.

\section{Conclusions}

When physicians make decisions on withdrawal of life-prolonging medical measures, for existence of criminal offence (against public health, individual health, body or life of a specific patient) and for illegality of their acts (of omission) crucial medical professional question remains whether such measures are medically unnecessary. This question will because of its actual nature have to be answered by appropriate experts (of medical profession) in criminal proceedings. If the thesis is confirmed, the complaint of professional error is of course excluded and thus also basically any possibility of conviction and any possible punitive measures against the offender, particularly, of course, the sentence. The question of substance of criminal offence or illegality hereby appears on primarily academic level and carries no decisive consequences for legal safety of health-care workers.

In current situation in Slovenia, it can quite clearly be concluded: if medical science and profession recognize certain medical measure, despite its ability to prolong life of a particular patient in a given case, as futile, this at least in case of (1) absence of opposition of a health-care proxy or patient's relatives without 

Care

adequate current or previously expressed patient's will to withdrawal of certain medical measures excludes medical error, and prevents any possibility of repressive response of criminal law. However, if the futility cannot be confirmed, we are in case of such omissions dealing with complex clusters of omissive criminal offences by a physician with typically fatal results.

In case of (2.) opposition of a health-care proxy or relatives to withdrawal of medical aid for reasons of the so-called futility with a potential or actual fatal result for the patient, the physician's decision-making remains, because of the fairly ambiguous legal regulation in ZPacP and in KZ-1 in this particular area, somewhat risky in terms of criminal law. In such cases, a very careful and detailed documentation of circumstances on which a decision on futility of certain medical measures was based, including absence of doubts, will certainly be crucial for the physician's legal safety (if we exceptionally for a moment do not consider the patient's legal safety). In such case, it seems that Slovenian criminal law should consider omission as non-existence of medical error with all indispensable and for a potential defendant categorically exonerating effects, and specifically exclusion of substance of all relevant omissive criminal offences (against public health, individual health, body and life of a specific patient), despite the explicit opposition of health-care proxy or relatives in such universally ethically, legally, and in particular generally humanly distressing matters.

\footnotetext{
Notes

${ }^{1}$ See for example the entire collection Trontelj.

${ }^{2}$ See the latest Slovenian sources, especially for example (Grosek et al., 2015).

${ }^{3}$ See especially Article 32 of ZPacP.

${ }^{4}$ The article is substantially in large parts based on central Slovenian monographic study of medical criminal law (Korošec, 2004) - the second edition in preparation and works cited therein, as well as on the commentary of ZPacP (Balažic et al., 2009).

5 "According to generally accepted theories of physical activity and the co-called theory of energy supply in causality as theories of distinction between induced acts and acts of omission, most theorists derive from the conviction that disconnecting a machine is an induced act and therefore active [...] (induced murder)."(Korošec 2004: 192, note 53). See also literature referred to therein.

${ }^{6}$ This dogmatics of conduct is comprehensively developed by modern German criminal law theory (in German original: "Abbruch eines rettenden Kausalverlaufs durch Abbruch Eigener [unausgeschöpften] Rettungsbemühungen"). See in particular (Haas 2002: 126, 129).

${ }^{7}$ See (Haas, 2002, in particular p. 129, as well as 131 and the literature listed therein).

${ }^{8}$ For detailed explanation of the latest findings in the field of omissive conduct, see in particular the entire monographic study by Kahlo.

${ }^{9}$ For general explanation on punishability of attempted real omissions, see, for example, (Jescheck \& Weigend, 1996: 637-639), and schematically in Slovenian literature, for example (Korosec, 2000: 192-193)!

${ }_{10}$ Slovenian legislator is traditionally very careless in dealing with interpersonality of criminal law at the level of substance of criminal offence as an element of general concept of criminal offence, and is unnecessarily introducing unusual value frictions into legislation
} 
by including numerous forms and sub-forms of self-harm in descriptions of criminal offences.

${ }^{11}$ This is true in spite of the generally accepted criminological definitory fact that with assistance in suicide, a psychological threshold of killing is crossed by a dying person himself (while with killing on request or with classic euthanasia, the psychological threshold of killing is crossed by another person).

12 For extensive explanation in Slovenian criminal law theory, see (Korošec, 2012)! Compare with a less critical, in relation to notoriously large systemic problems related to the use of notion of aggravated consequences in special part of Slovenian criminal law (including medical criminal law) sometimes even desimulative latest approach in (Bavcon \& Šelih, 2013: 305-306)!

${ }^{13}$ For more details, see Slovenian criminal law literature, in particular the relevant chapter in (Bavcon et al, 1998).

${ }^{14}$ For disponibility of legal interests, see Slovenian criminal law literature, in particular, for example (Korošec 1997).

\section{References}

Balažic, J., Brulc, U., Ivanc, B., Korošec, D., Kralj, K., Novak, B. Pirc Musar, N., \& Robida, A. (eds.) (2009) Zakon o pacientovih pravicah (ZPacP) s komentarjem (Ljubljana: GV založba).

Bavcon, L., Šelih, A., Korošec, D., Ambrož, M. \& Filipčič, K. (2013) Kazensko pravo splošni del, 6. ed. (Ljubljana: Uradni list RS).

Deisinger, M. (2002) Kazenski zakonik s komentarjem - posebni del (Ljubljana: Gospodarski vestnik).

Grosek, Š., Grošelj, U. \& Oražem, M. (eds.) (2015) Etična priporočila za odločanje o zdravljenju in paliativni oskrbi bolnika ob koncu življenja $v$ intenzivni medicini (Ljubljana: Univerzitetni klinični center Ljubljana).

Haas, V. (2002) Kausalität und Rechtsverletzung - ein Beitrag zu den Grundlagen strafrechtlicher Erfolgshaftung am Beispiel des Abbruchs rettender Kausalverläufe (Berlin: Duncker \& Humblot).

Jescheck, H.-H. \& Weigend, T. (1996) Lehrbuch des Strafrechts - Allgemeiner Teil (Berlin: Dunckner \& Humblot Verlag).

Kahlo, M. (2001) Die Handlungsform der Unterlassung als Kriminaldelikt. Eine strafrechtlich-rechtsphilosophische Untersuchung zur Theorie des personalen Handelns. (Frankfurt am Main: Vittorio Klostermann).

Korošec, D. (1997) Potencialni oškodovanec po sodobnem materialnem kazenskem pravu volenti non fit iniuria?, Zbornik znanstvenih razprav Pravne fakultete v Ljubljani, 57, pp. 189-218.

Korošec, D. (2000) Vidnejše posebnosti opustitvenih kaznivih dejanj, Zbornik znanstvenih razprav Pravne fakultete v Ljubljani, 59(1), pp. 179-198.

Korošec, D. (2004) Medicinsko kazensko pravo (Ljubljana: Cankarjeva založba).

Korošec, D. (2012) Zelo kritično o institutu hujše posledice v slovenskem kazenskem pravu. Pravna praksa, 31(19), pp. 2-6.

Trontelj J. (2014) Živeti z etiko (Ljubljana: Inštitut za etiko in vrednote Jože Trontelj). 